\title{
Description of a bilateral gynandromorph in Spodoptera frugiperda (Smith, 1797) (Lepidoptera: Noctuidae) from Brazil
}

\author{
Natália de Souza Ribas ${ }^{*}$ (D), Jhon Faber Marulanda Lopez ${ }^{2,3}$ (D), Eraldo Lima1 \\ ${ }^{1}$ Universidade Federal de Viçosa, Departamento de Entomologia, Laboratório de Semioquímicos e Comportamento de Insetos, Viçosa, \\ $M G$, Brasil. \\ ${ }^{2}$ Universidade Federal de Viçosa, Departamento de Entomologia, Museu de Entomologia, Viçosa, Minas Gerais, Brasil. \\ ${ }^{3}$ Universidad de Caldas, Facultad de Ciencias Exactas y Naturales, Grupo de Investigación Bionat, Manizales, Colombia.
}

\section{A R T I C L E I N F O}

Article history:

Received 23 November 2020

Accepted 26 April 2021

Available online 12 May 2021

Associate Editor: Héctor Vargas

\begin{abstract}
A B S T R A C T
A bilateral gynandromorph of Spodoptera frugiperda was reported for the first time from Minas Gerais State Brazil. The specimen with this trait was found among the progeny of a laboratory rearing population and exhibited dimorphism in the antennae, wings, head, thorax, and abdomen. It had a male left side and a female right side. Both the external and internal genitalia were typically those of a male.
\end{abstract}

Gynandromorphs are chimeric individuals that present masculine and feminine tissues in its body (Narita et al., 2010). They have been found in natural and laboratory populations of arthropods (Maeno and Tanaka, 2007; Sagar et al., 2020). According to the distribution of male and female features throughout the body, gynandromorphs are classified into anteroposterior (anterior and posterior sides are of different sexes), bilateral (right and left sides are of different sexes), transversal (asymmetric distribution), or mosaic distribution (random distribution of characters along the body) (Michez et al., 2009). The bilateral gynandromorphism is more frequent among insects, although other forms with any distribution of sexual characters are also known (Dutto et al., 1767; Dang and Peterson, 1979; Davis, 1994; D'Entreves and Roggero, 2013; Renjith and Chandran, 2020). This phenomenon is more frequent in invertebrates than vertebrates, with some reports in birds (Zhao et al., 2010; Morris et al., 2018). Even in invertebrates, it is considered rare in nature, but relatively common among bees, especially in Megachile sp. (Wcislo et al., 2004).

In Lepidopterans, sexual dichromatism is present and evident, principally in the wing color. Many gynandromorph specimens have

\footnotetext{
* Corresponding author.

E-mail: natalia.sribas@gmail.com (N.S. Ribas).
}

been reported for butterflies (e.g. in Lycaenidae, Nymphalidae, Pieridae, Papilionidae, Geometridae) (Emmel and Boender, 1990; Kutis and Heppner, 1990; Bernardino et al., 2007; Nielsen, 2010; Jahner et al., 2015; Bollino and Padrón, 2016; Seven and Özdemir, 2017), but also for some moths, like in Noctuidae species as Agrotis segetum and $A$. ipsilon (Blair, 1976; Gemeno et al., 1998).

The fall armyworm (FAW) Spodoptera frugiperda (Smith, 1797) is the most important corn pest in South America and is a global pest of corn occurs worldwide (Blanco et al., 2016; Fan et al., 2020). A gynandromorph FAW adult was found and reported for the first time in Minas Gerais State, Brazil, among the progeny of a transgenic Bt corn susceptible laboratory rearing population (Bahia-Cv) (SantosAmaya et al., 2016). This population was maintained in controlled conditions ( $27 \pm 3^{\circ} \mathrm{C}, 70 \pm 15 \% \mathrm{RH}$, and 14:10 h L/D photoperiod) in the Semiochemical Laboratory of the Entomology Department in the Federal University of Viçosa, Brazil.

The gynandromorph moth emerged from a male pupa that had been sexed using the morphological features on the terminal abdominal segments. Prior to imaging, the specimen was maintained at $-15^{\circ} \mathrm{C}$ for 5 minutes to remain immobile. We used a Faxitron X-Ray Corp (Wheeling, IL, USA) and a LEICA M205 A Stereomicroscope coupled 


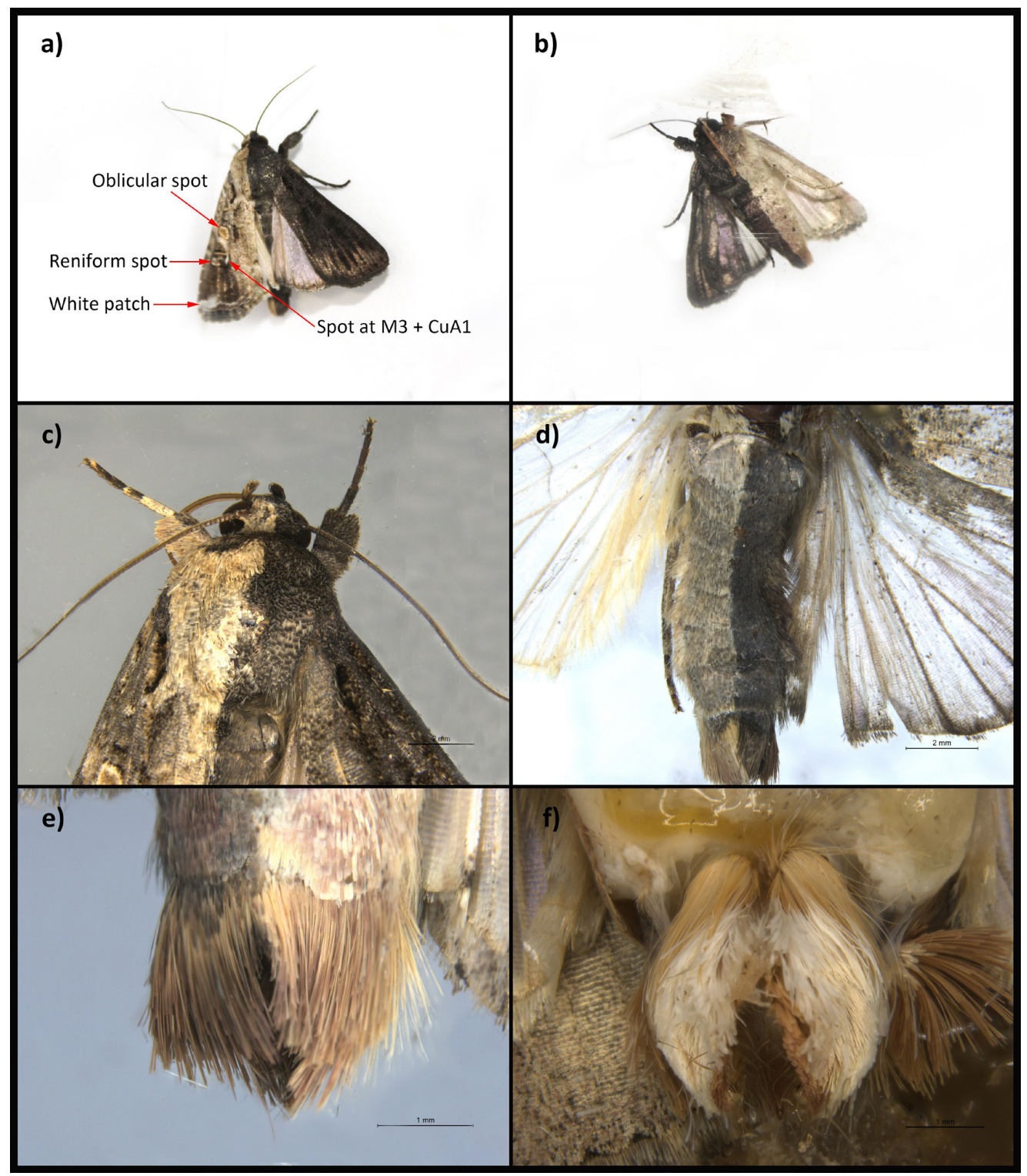

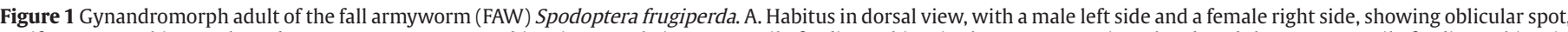

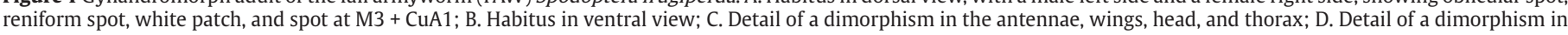
the abdomen; E. Last abdominal segment; F. Last abdominal segment of a normal male FAW.

with a LEICA MC170 HD camera in the Ecotoxicology and Ecophysiology Laboratory and in the Termitology Laboratory of the Federal University of Viçosa, respectively. The gynandromorph specimen was deposited in the Entomology Museum of the Federal University of Viçosa.

The moth (Fig. 1a-f) exhibited bilateral dimorphism in the antennae, wings, head, thorax, and abdomen. It had a male left side and a female right side (Fig. 1a). The genitalia were typically those of a male(Fig. 1e, 1f) and (Fig. 2a-c). The clasper was visible in the X-ray image, but it appears to be less developed than that of a normal FAW (Fig. 2a, 2c) (Quimbayo et al., 2010). Sagar et al. (2020) already reported a bilateral gynandromorph for a FAW in natural conditions, although the specimen presented asymmetrical genitalia with male structures in one half of the body and female in the other.

The forewing of the male side had a brownish to rusty brown color, with a white patch near to the apical margin and a longitudinal black line near to the basal margin (Fig. 1a). It had an oval yellowish-brown oblicular spot and a reniform spot with an outline partially black washed, with a small white v-like marking (Fig. 1a). In addition, a conspicuous transparent spot in the $\mathrm{M} 3$ and $\mathrm{CuA} 1$ veins junction was seen (Fig. 1a). The forewing of the female side had a greyish-black color
(Figs. 1a, 1b). Both hindwings were white, with outer, anal, and inner margins black washed, mainly on the female side (Fig. 1d). The male side abdomen had a brownish color and the female side a greyishblack color (Fig. 1d). In ventral view, each abdominal sternite had a central black marking (Fig. 1b). All these traits were similar to those of a normal FAW specimen (Brévault et al., 2018; Sharanabasappa et al., 2018; Bajracharya et al., 2019).

Gynandromorphism is produced by an unequal distribution of chromosomes, especially the sexual (Mayr et al., 1953). They normally result from either loss or addition of a sex chromosome early during development, from fertilization of a binucleated egg, or delayed syngamy (Cooper, 1959; Homsher and Yunker, 1981; Narita et al., 2010). Some of the known reasons for the gynandromorph abnormalities are extreme temperatures, ultraviolet light, viral infections, and translocations of parts of the sex chromosomes and/or autosomes (Drescher and Rothenbuhler, 1963; Nekrutenko, 1965; Blau, 1978; Riotte, 1978; Marec et al., 2001). For Lepidopteran like Bombyx mori, that have a female-heterogametic chromosomal constitution (i.e., ZZ: male; ZW: female), double fertilization of a binucleate egg (ZW) by Z 

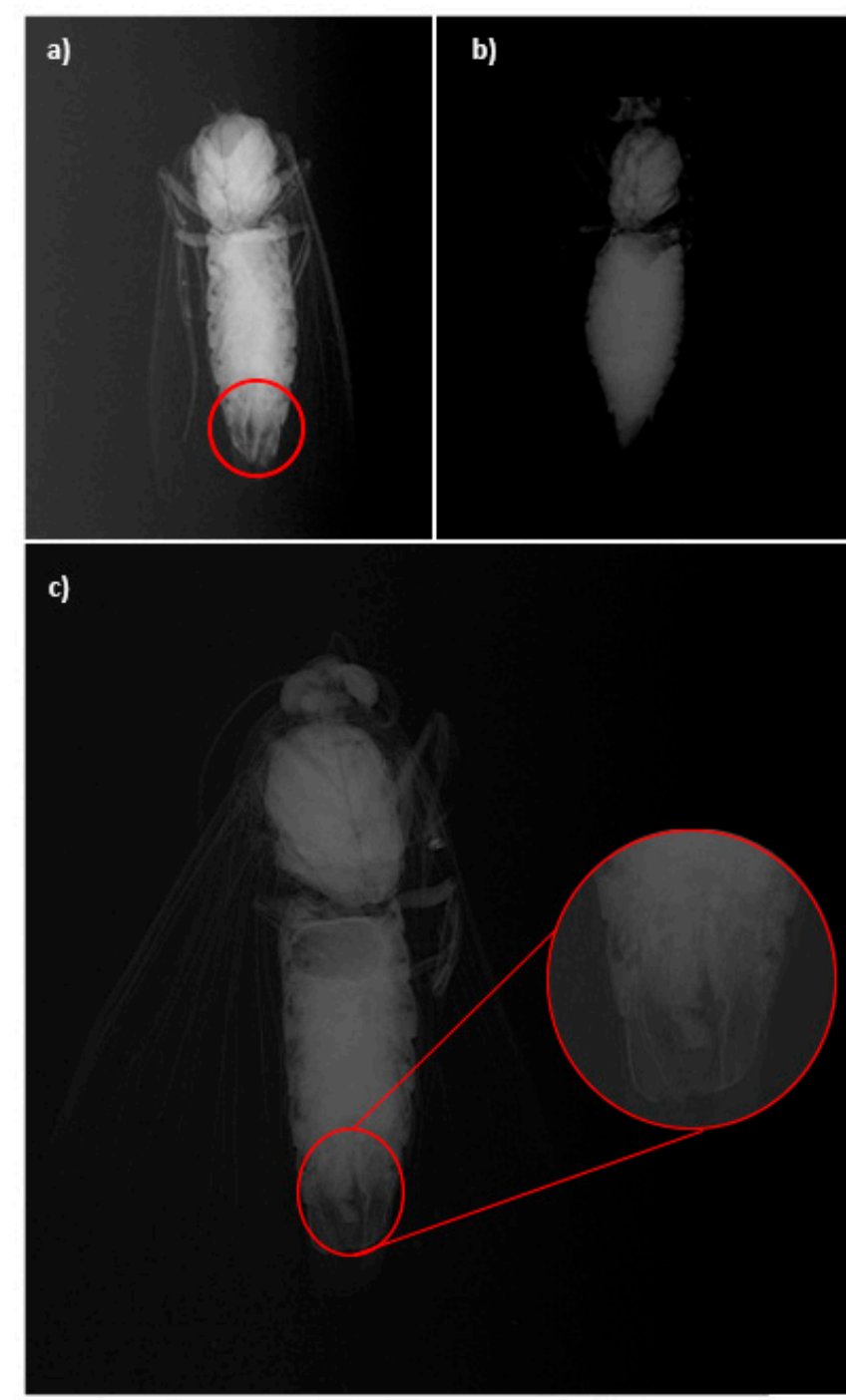

Figure 2 Faxitron X-Ray of a gynandromorph adult of the fall armyworm (FAW) Spodoptera frugiperda. A. Faxitron X-Ray of a normal FAW male with a red circle showing the clasper; B. Faxitron X-Ray of a normal FAW female; C. Faxitron X-Ray of a gynandromorph FAW with a red circle with a zoom evidencing the clasper.

sperms is thought to be the major cause of gynandromorphs generation (Goldschmidt and Katsuki, 1927). Other potential causal agents of gynandromorphism are the mutations, genetic incompatibilities, and Wolbachia infection (Pereira et al., 2003; Kageyama et al., 2012). We encourage the worldwide biological collections to document the gynandromorphic and aberrant individuals deposited, such as the frequency and morphology of their deformities, an important information with applications in pest management and biomedicine (Narita et al., 2010; Sánchez-Murillo et al., 2013; Eastwood and Wood, 2019).

\section{Acknowledgments}

This study was financed in part by the Coordenação de Aperfeiçoamento de Pessoal de Nível Superior - Brasil (CAPES) - Finance Code 001, Fundação de Amparo à Pesquisa do Estado de Minas Gerais (FAPEMIG) and Conselho Nacional de Desenvolvimento Científico e Tecnológico (CNPq) - INCT Semioquímicos na Agricultura. The second author thanks Conselho Nacional de Desenvolvimento Científico e
Tecnológico (CNPq) for his scholarship (process \# 162813/2018-0). We thank Lírio Cosme Júnior and the Laboratório de Ecotoxicologia e Ecofisiologia for the support to use the X-Ray. We also thank Og De Souza and the Termitology Laboratory for making available the optic equipment for image taking. We thank Hernane Dias Araújo for revising the manuscript and also the two anonymous reviewers that helped to improve the final version of this scientific note.

\section{Conflicts of interest}

The authors declare that they have no conflict of interest.

\section{Author contribution statement}

All authors contributed to the study conception. NDSR conceived the research, conducted the laboratory work and wrote the document. JFML elaborated the final plates and the morphological description of the specimen. ERL supported the rearing of the specimens and disponibilize the laboratory for developing this research. All authors read, critically reviewed and approved the final version of this scientific note.

\section{References}

Bajracharya, A. S. R., Bhat, B., Sharma, P., Shashank, P. R., Meshram, N. M., Hashmi, T. R., 2019. First record of fall armyworm Spodoptera frugiperda(JE Smith) from Nepal. Indian J. Entomol. 81 (4), 635-639. http://dx.doi.org/10.5958/0974-8172.2019.00137.8.

Bernardino, A. S., Zanuncio, T. V., Zanuncio, J. C., Lima, E. R., Serrão, J. E., 2007. Note on gynandromorphism in the eucalyptus defoliator Thyrinteina arnobia (Stoll, 1782) (Lepidoptera: geometridae). An. Acad. Bras. Cienc. 79 (2), 235-237. http://dx.doi.org/10.1590/S000137652007000200006.

Blair, B. W., 1976. A gynandromorph of Agrotis segetum (Denis \& Schiff.) (Lepidoptera: Noctuidae): scientific note. J. Entomol. Soc. South. Afr. 39 (1), 151.

Blanco, C. A., Chiaravalle, W., Dalla-Rizza, M., Farias, J. R., García-Degano, M. F., Gastaminza, G., Mota-Sánchez, D., Murúa, M. G., Omoto, C., Pieralisi, B. K., Rodríguez, J., Rodríguez-Maciel, J. C., Terán-Santofimio, H., Terán-Vargas, A. P., Valencia, S. J., Willink, E., 2016. Current situation of pests targeted by Bt crops in Latin America. Curr. Opin. Insect Sci. 15, 131-138. http://dx.doi.org/10.1016/j.cois.2016.04.012.

Blau, W. S., 1978. A gynandromorph of Papilio polyxenes(Papilionidae). J. Lepid. Soc. (32), 138-139.

Bollino, M., Padrón, P. S., 2016. Description of a new subspecies of Catasticta fulva Joicey \& Rosenberg, 1915, with notes on several other species in the genus (Lepidoptera: pieridae). Trop. Lepid. Res. 26 (1), 1-5.

Brévault, T., Ndiaye, A., Badiane, D., Bal, A. B., Sembène, M., Silvie, P., Haran, J., 2018. First records of the fall armyworm, Spodoptera frugiperda (Lepidoptera: Noctuidae), in Senegal. Entomol. Gen. 37 (2), 129-142. http://dx.doi.org/10.1127/entomologia/2018/0553.

Cooper, K. W., 1959. A Bilaterally Gynandromorphic Hypodynerus, and a summary of cytologic origins of such mosaic Hymenoptera. Biology of Eumenine Wasps, VI. Bull. Fla. State Mus. Biol. Sci. 5 (2), 25.

D'Entreves, P., Roggero, A., 2013. The first case of gynandromorphism in Enolmis (Lepidoptera: Gelechioidea: Scythrididae). Acta Entomol. Musei Entomol. Musei Nationalis Pragae 53 (1), 369-380.

Dang, P. T., Peterson, B. V., 1979. A case of bilateral gynandromorphism in Simulioum soubrense Vajime and Dunbar (Diptera: simuliidae). Tropenmed. Parasitol. 30 (4), 548-550. 
Davis, D. R., 1994. A bilateral gynandromorphic Harmaclona tephrantha from Indonesia (Lepidoptera: tineidae). Trop. Lepid. Res. 5 (2), 117-122.

Drescher, W., Rothenbuhler, J., 1963. Gynandromorph production by egg chilling. J. Hered. (82), 165-170.

Dutto, M., Penna, M., Sama, G. A., 1767. First case of gynandromorphism in Stenopterus ater (linnaeus, 1767) (Coleoptera, Cerambycidae). Zoology 6 (1), 508-511.

Eastwood, R., Wood, G. A., 2019. Description of a Quadrilateral Mosaic Gynandromorph of Hypolimnas bolina nerina (Fabricius, 1775) (Nymphalidae) from Northern Queensland, Australia. J. Lepid. Soc. 73 (3), 145-148. http://dx.doi.org/10.18473/lepi.73i3.a2.

Emmel, T. C., Boender, R. O. N. A. L. D., 1990. An extraordinary hybrid gynandromorph of Heliconius melpomene subspecies (Lepidoptera: nymphalidae). Trop. Lepid. 1 (1), 33-34.

Fan, J., Wu, P., Tian, T., Ren, Q., Haseeb, M., Zhang, R., 2020. Potential distribution and niche differentiation of Spodoptera frugiperda in Africa. Insects 11 (6), 383. http://dx.doi.org/10.3390/insects11060383.

Gemeno, C., Anton, S., Zhu, J. W., Haynes, K. F., 1998. Morphology of the reproductive system and antennal lobes of gynandromorphic and normal black cutworm moths, Agrotis ipsilon (Hufnagel) (Lepidoptera: noctuidae). Int. J. Insect Morphol. Embryol. 27 (3), 185-191. http://dx.doi.org/10.1016/S0020-7322(98)00010-5.

Goldschmidt, R., Katsuki, K., 1927. Erheblicher Gynandromorphismus und somatische Mosaikbildung bei Bombyx mori L. Biol. Zent. Bl. (47), 45-54.

Homsher, P. J., Yunker, C. E., 1981. Bilateral gynandromorphism in Dermacentor andersoni (Acari: Ixodidae): morphologic and cytogenetic analysis. J. Med. Entomol. 18 (1), 89-91. http://dx.doi. org/10.1093/jmedent/18.1.89.

Jahner, J. P., Lucas, L. K., Wilson, J. S., Forister, M. L., 2015. Morphological outcomes of gynandromorphism in Lycaeides butterflies (Lepidoptera: lycaenidae). J. Insect Sci. 15 (1), 38. http://dx.doi.org/10.1093/ jisesa/iev020.

Kageyama, D., Narita, S., Watanabe, M., 2012. Insect sex determination manipulated by their endosymbionts: incidences, mechanisms and implications. Insects 3 (1), 161-199. http://dx.doi.org/10.3390/ insects3010161.

Kutis, J. S., Heppner, J. B., 1990. Gynandromorph of Nacophora quernaria in Florida (Lepidoptera: geometridae). Trop. Lepid. Res. 1 (1), 42.

Maeno, K., Tanaka, S., 2007. Morphological and behavioural characteristics of a gynandromorph of the desert locust, Schistocerca gregaria. Physiol. Entomol. 32 (3), 294-299. http://dx.doi.org/10.1111/j.13653032.2007.00573.x.

Marec, F., Tothová, A., Sahara, K., Traut, W., 2001. Meiotic pairing of sex chromosome fragments and its relation to atypical transmission of a sex-linked marker in Ephestia kuehniella (Insecta: lepidoptera). Heredity 87 (6), 659-671. http://dx.doi.org/10.1046/j.13652540.2001.00958.x.

Mayr, E., Linsley, E. G., Usinger, R. L., (1953). Methods and Principles of Systematic Zoology. Cambridge University Press, Cambridge, 93 pp.

Michez, D., Rasmont, P., Terzo, M., Vereecken, N. J., 2009. A synthesis of gynandromorph among wild bees (Hymenoptera: Apoidea), with an annotated description of several new cases. Ann. Soc. Entomol. Fr. 45 (3), 365-375. http://dx.doi.org/10.1080/00379271.2009.10697621.
Morris, K. R., Hirst, C. E., Major, A. T., Ezaz, T., Ford, M., Bibby, S. Doran, T. J., Smith, C. A., 2018. Gonadal and endocrine analysis of a gynandromorphic chicken. Endocrinology 159 (10), 3492-3502. http://dx.doi.org/10.1210/en.2018-00553.

Narita, S., Pereira, R. A. S., Kjellberg, F., Kageyama, D., 2010. Gynandromorphs and intersexes: potential to understand the mechanism of sex determination in arthropods. Terr. Arthropod Rev. 3 (1), 63-96. http://dx.doi.org/10.1163/187498310X496190.

Nekrutenko, Y. P., 1965. Three cases of gynandromorphism in Gonepteryx: an observation with ultraviolet rays. J. Res. Lepid. (4), 103-108.

Nielsen, J. E., 2010. A review of gynandromorphism in the genus' Ornithoptera' Boisduval (Lepidoptera: papilionidae). Aust. Entomol. 37 (3), 105.

Pereira, R. A. S., Prado, A. P., Kjellberg, F., 2003. Gynandromorphism in pollinating fig wasps (Hymenoptera: agaonidae). Entomol. News 114 (3), 152-155.

Quimbayo, N., Serna, F., Olivares, T. S., Angulo, A. O., 2010. Nóctuidos (Lepidoptera) en cultivos de flores colombianas. Rev. Colomb. Entomol. 36 (1), 38-46.

Renjith, R. V., Chandran, A. V., 2020. A record of gynandromorphism in the libellulid dragonfly Crocothemis servilia(Insecta: Odonata) from India. J. Threat. Taxa 12 (9), 16183-16186. http://dx.doi.org/10.11609/ jott.5322.12.9.16183-16186.

Riotte, J. C. E., 1978. Gynandromorphs in Hawaiian butterflies and moths. J. Res. Lepid. (17), 17-18.

Sagar, D., Shashank, P. R., Isaiyamudhini, T., Sujatha, G. S., Komal, J., 2020. Gynandromorph in fall armyworm, Spodoptera frugiperda (Lepidoptera: noctuidae). Curr. Sci. 119 (12), 1898-1900.

Sánchez-Murillo, J. M., Alarcón-Elbal, P. M., González-López, M., DelacourEstrella, S., Lucientes, J., 2013. Description of two gynandromorphs of Culex theileri from Extremadura, Spain. J. Am. Mosq. Control Assoc. 29 (1), 61-63. http://dx.doi.org/10.2987/12-6256.1.

Santos-Amaya, O. F., Rodrigues, J. V., Souza, T. C., Tavares, C. S., Campos, S. O., Guedes, R. N., Pereira, E. J., 2016. Resistance to dual-gene Bt maize in Spodoptera frugiperda: selection, inheritance, and crossresistance to other transgenic events. Sci. Rep. 5 (1), 18243. http:// dx.doi.org/10.1038/srep18243.

Seven, S., Özdemir, M., 2017. Morphological analyses of two gynandromorphy individuals of Geometridae (Lepidoptera: geometridae). SHILAP Rev. Lepidopterol. 45 (177), 37-46.

Sharanabasappa, Kalleshwaraswamy, C. M., Asokan, R., Mahadeva Swamy, H. M., Maruthi, M. S., Pavithra, H. B., Hedge, K., Navi, S., Prabhu, S. T., Goergen, G., 2018. First report of the fall armyworm, Spodoptera frugiperda (J E Smith) (Lepidoptera: Noctuidae), an alien invasive pest on maize in India. Pest Manage. Hortic. Ecosyst. 24 (1), 23-29.

Wcislo, W. T., Gonzalez, V. H., Arneson, I., 2004. A review of deviant phenotypes in bees in relation to brood parasitism, and a gynandromorph of Megalopta genalis (Hymenoptera: halictidae). J. Nat. Hist. 38 (11), 1443-1457. https://doi.org/10.1080/00222930 31000155322.

Zhao, D., McBride, D., Nandi, S., McQueen, H. A., McGrew, M. J., Hocking, P. M., Lewis, P. D., Sang, H. M., Clinton, M., 2010. Somatic sex identity is cell autonomous in the chicken. Nature 464 (7286), 237-242. http://dx.doi.org/10.1038/nature08852. 